\title{
STRUKTUR TEKS KARANGAN BAHASA JEPANG: ANALISIS PADA KARANGAN MAHASISWA ANGKATAN 2013
}

\author{
Didik Nurhadi \\ Universitas Negeri Surabaya, didiknurhadi@unesa.ac.id
}

\begin{abstract}
This article aimed to describe a essay of Unesa Student 2013 class, relating to the structure of text and error analysis of Japanese language. These two viewpoints are considered important to see the student essay, with the reason that both of viewpoints relevant to the purpose of learning Japanese language 'sakubun' that is capable to communicate a case, circumstances, events, and opinions on to written language communication in good and right. The object were taking from student essay results of Prodi Japanese Language and Education with total 22 students. The obtained data will be analyzed using interpretive methods to student essay of Unesa student 2013class, to describe the characteristics construction of essay text relating to the use of conjunctions and classification as well as text categorization based on the sentence or main paragraph placement.
\end{abstract}

Keywords: text structure, conjunctions, main sentence, text classification

\section{PENDAHULUAN}

Pembelajaran bahasa Jepang di lembaga pendidikan tinggi termasuk Universitas Negeri Surabaya (selanjutnya disebut Unesa) secara umum bertujuan untuk mengasah kemampuan berkomunikasi baik secara lisan maupun tulisan dalam bahasa Jepang. Masing-masing kemampuan diasah secara seimbang dalam setiap pembelajaran bahasa Jepang. Berkaitan dengan tingkat kemampuan berkomunikasi bahasa Jepang mahasiswa asing, khususnya kemampuan menulis bahasa Jepang pembelajar asing masih perlu ditingkatkan lagi (periksa Tashiro: 2005, 2006, Tsuchida dan Imai: 2007, 2008). Tashiro (2005) menegaskan tentang kesulitan pembelajar bahasa Jepang khususnya pembelajar tingkat menengah dan mahir mengungkapkan pikirannya dalam karangan karena ketidakcukupan pengetahuan dan pemahaman tatabahasa dan kosakata bahasa Jepang. 
Tashiro (2006) melanjutkan penelitiannya dengan mengambil subjek penelitian pembelajar dari China dan Korea untuk menyelidiki faktor-faktor penyebab karangan pembelajar susah dipahami oleh penutur bahasa Jepang. Penelitian ini pun menegaskan kembali hasil penyelidikan Tashiro (2005) yang menyimpulkan bahwa kemampuan pembelajar dari kedua negara tersebut menyangkut tatabahasa dan kosakata yang masih belum cukup mencukupi khususnya dalam hal penggunaan dalam konteks yang luas, sehingga menyebabkan karangan yang dibuat susah dipahami. Bahkan Tashiro (2005) menegaskan tentang faktor penyebab karangan pembelajar bahasa Jepang susah dipahami sebagai berikut.

文章のわかりにくさは多くの要因が絡んでいるが、日本語学習者の文章 の問題点については、文章構造に着目した研究、文脈展開の方法に見い だしている研究が多い。このように文章の問題は構造や文脈展開に多く の注目が集まってきたが、実際にはそればかりではなく、ボトムアップ 処理に関する問題、例えば1文単位の言語的側面にも要因があると考えら れる。

Pendapat di atas menegaskan bahwa faktor-faktor penyebab karangan mahasiswa pembelajar bahasa Jepang sulit dipahami dikarenakan beragam alasannya, selain berkaitan dengan pemahaman akan struktur teks dan komposisi teks, banyak faktor-faktor lain yang berkaitan dengan permasalahan tersebut. Persoalan ini tidak lepas dari karakteristik kemampuan menulis sebagai kemampuan komplek yang biasanya menjadi persoalan dalam pembelajaran bahasa mengingat kemampuan ini banyak dipengaruhi kemampuan lain seperti kemampuan penguasaan kosakata, tata kalimat juga kemampuan mengorganisasikan seluruh komponen pembentuk satuan bahasa misalnya satuan kalimat menjadi satu kesatuan utuh yang membentuk koherensi dalam karangan tersebut.

Permasalahan kemampuan membuat karangan dalam pelajaran bahasa Jepang, dalam ungkapan bahasa Jepang disebutkan dalam istilah 'sakubunryoku' atau 
kemampuan menulis secara umum telah dikupas dalam Tashiro $(2005,2006)$ yang menyebutkan bahwa kendala pembelajar asing bahasa Jepang terkait dengan kemampuan membuat karangan yakni pembelajar kurang mampu mengorganisasikan kalimat, kurang mampu menyebutkan atau menentukan pokok persoalan yang menjadi bahasan dalam karangan, kurang mampu menggunakan kosakata dan konteksnya secara baik.

Pendapat-pendapat di atas sejalan pula dengan hasil pengamatan dan pengalaman penulis selama mengampu mata kuliah mengarang dalam bahasa Jepang 'sakubun' pada Prodi Pendidikan Bahasa Jepang Unesa. Banyak mahasiswa mengalami kesulitan menuangkan pikiran, ide, dan gagasan dalam bahasa Jepang secara baik, terutama permasalahan tentang kesulitan mengorganisasikan pokok pikiran, kesulitan memilih ungkapan yang tepat, kesulitan dalam menulis huruf kanji, kurang memahami struktur teks, tidak memahami kohesi dan koherensi teks, kurang memahami bagaimana menempatkan kalimat pokok, paragraf pokok dan berbagai permasalahan pembelajaran kemampuan menulis lainnya. Semua permasalahan tersebut bermuara pada karangan bahasa Jepang yang tidak alamiah, karangan bahasa Jepang yang tidak dapat dipahami oleh penutur asli bahasa Jepang.

Mengapa sakubun harus mempunyai sasaran bagi pembelajar yakni membekali dengan mampu menggunakan bahasa Jepang alamiah? Jawabannya tidak lain karenaseperti yang diketahui bersama bahwa bahasa Jepang (bahasa lainnya pun demikian) mempunyai aturan spesifik terkait konteks penggunaan ungkapanungkapan yang ada, bahasa Jepang mengakomodir konteks spesifik dengan menggunakan ungkapan, tatabahasa, dan kosakata yang spesifik pula. Sakubun sebagai mata kuliah yang dikhususkan untuk mengasah pembelajar menuangkan pikiran, ide, dan gagasan dalam teks karangan bahasa Jepangsecara alamiah dengan memperhatikan aturan-aturan 'kealamiahan' agar dapat dipahami pembelajar bahasa Jepang maupun penutur asli bahasa Jepang. Memang sasaran pada masing-masing level pembelajaran sakubun bahasa Jepang berbeda satu dengan lain, dan selalui 
disesuaikan dengan tingkat pembelajaran dari level dasar sampai level mahir. Namun pada intinya, semua sepakat bahwa kemampuan menulis bahasa Jepang dituangkan dalam sasaran pokok dalam mata kuliah Sakubun.

Alasan-alasan yang berkaitan dengan kesulitan pembelajarbahasa Jepang dalam menuangkan pikiran, gagasan dan ide mendorong pentingnya penelitianpenelitian yang mengangkat permasalahan sakubun seperti dalam penjelasan di atas perlu dilaksanakan segera. Namun sayangnya penelitian-penelitian yang seperti itu belum banyak dilakukan, khususnya penelitian yang mengambil subjek pembelajar bahasa Jepang dari Indonesia. Hasil pemeriksaan penelitian yang mendahului didapatkan hasil bahwa penelitian tentang sakubun banyak dilakukan menyangkut faktor-faktor penyebab kesulitan pemahaman hasil karangan pembelajar bahasa Jepang dari China dan Korea dalam penelitian Tashiro (2005, 2006).

Mendasarkan pada latar belakang penelitian yang telah dirinci dalam bahasan awal dalam subbab ini, penelitian ini khususnya berkaitan dengan penyelidikan klasifikasi struktur menurut penempatan kalimat pokok dan jenis serta frekuensi penggunaan kata sambung dalam membentuk untuk mengetahui gambaran komprehensif struktur teks karangan mahasiswa Prodi Pendidikan Bahasa Jepang Unesa dari dua sudut pandang yakni konstruksi teks (linguistik Formal) dan analisis kesalahan berbahasa (linguistik praktis).

Fokus penelitian yang berlatarbelakang kemampuan menulis dalam bahasa Jepang 'sakubun' dewasa ini yakni berkaitan dengan tema tentang kemampuan dan kecenderungan penggunaan ungkapan-ungkapan tertentu dalam karangan oleh mahasiswa asing. Sebagian besar penelitian mengajukan penelitian perbandingan subjek penelitian antara native speaker dengan pembelajar bahasa Jepang dari China dan Korea (periksa Tanaka: 2015, Tashiro: 2006).

Tanaka (2015) menyelidiki tentang penggunaan kata kerja Omou 'berpendapat, berfikir' khususnya tentang frekuensi penggunaan dan bentuk penggunaan kata kerja tersebut dalam karangan mahasiswa pembelajar bahasa Jepang 
dan mahasiswa Jepang (native speaker). Penelitian ini mengajukan simpulan yakni frekuensi penggunaan kata kerja omou oleh pembelajar bahasa Jepang dalam karangannya tidak terlalu banyak muncul/digunakan dalam karangan mahasiswa asing pembelajar bahasa Jepang bila dibandingkan dengan karangan dari mahasiswa Jepang. Bentuk penggunaan kata kerja omou didekati dalam empat aspek yakni bentuk konjugasi, partikel awal yang mengikuti kata kerja omou, penggunaan omou dalam kalimat atau wacana yang alami, dan kata kerja omou yang digabungkan dengan partikel to untuk menyatakan kutipan/pendapat orang lain. Masing-masing aspek yang diteliti dalam penelitian tersebut menunjukkan adanya perbedaan penggunaan antara mahasiswa asing dan mahasiswa Jepang baik dari tinjauan frekuensi maupun bentuk penggunaan kata kerja omou yang alami dalam komunikasi berbahasa Jepang.

Tashiro (2005, 2006) mengajukan permasalahan tentang penyebab karangan bergenre ekspositori ceritayang dibuat pembelajar bahasa Jepang sulit dipahami oleh native speaker bahasa Jepang. Tashiro membuat perbandingan antara teks karangan mahasiswa pembelajar bahasa Jepang yang sulit dipahami dengan karangan native speaker/pembelajar bahasa Jepang yang mudah dipahami, kemudian dilihat perbedaan dan persamaan masing-masing teks karangan tersebut. Perbedaan yang amat menyolok antara teks karangan yang mudah dipahami (teks karangan native speaker dan beberapa karangan pembelajar bahasa Jepang) dengan karangan yang sulit dipahami maknanya terdapat pada tataran kosakata yang dipakai, konstruksi kalimat, dan jumlah informasi yang disampaikan dalam teks yang sulit dipahami cenderung sedikit. Sedangkan berkaitan dengan konstruksi teks, teks karangan yang yang sulit dipahami cenderung menggunakan bentuk-te untuk menyambungkan antar klausa, kalimat dalam konstruksi teks secara keseluruhan.

Tashiro (2009) melanjutkan analisisnya dengan penelitian eksperimen untuk menilai hasil karangan teks argumentatif mahasiswa dengan menggunakan standar penilaian tertentu untuk menemukan titik-titik permasalahan tentang penyebab sulitnya karangan pembelajar bahasa Jepang dipahami oleh orang Jepang. 
Simpulannya mengangkat permasalahan tentang panjang-pendeknya karangan mahasiswa, jumlah informasi yang disampaikan melalui karangan tersebut, permasalahan koherensi karangan, permasalahan dari segi makna teks secara keseluruhan.

Komunikasi berbahasa manusia diimplementasikan dalam bentuk kumpulan berbagai informasi yang diwujudkan dalam bentuk kalimat-kalimat (jika komunikasinya berbentuk bahasa tulis) atau ujaran-ujaran (jika komunikasnya berbentuk bahasa lisan) yang saling berkaitan satu dengan lainnya membentuk satu kesatuan untuk menyampaikan maksud tertentu. Pada umumnya, jarang sekali ditemukan komunikasi yang berbentuk satu kalimat/ujaran saja.Satuan terbesar dan terlengkap dalam komunikasi berbahasa disebut teks atau wacana.

Tokieda (1950) menyimpulkan bahwa penelitian bahasa secara ilmiah sebagai bagian dalam penelitian ketatabahasaan selain bidang morfologi dan sintaksis, perlu menambah satuan yang lebih besar yakni teks sebagai bagian penelitian ketatabahasaan. terkait dengan simpulan tersebut, Tokieda (1950:21) mengemukakan pendapatnya sebagai berikut.

言語の究極的単位として単語を考え、単語を基本とし、出発点として 、その結合に於いて言語を考えていこうとする構成的な考え方をとら ないで、分析以前の統一体としての言語的事実を捉え、それを記述す ることから出発しようとする。

(dalam menganalisis teks, saya menangkap kenyataan secara linguistik bahwa teks merupakan satu kesatuan utuh pada saat sebelum dianalisis, karenanya saya memulai mendeskripsikan hal itu dengan tidak menggunakan sudut pandang yang mendasarkan pada pemikiran bahwa kata menjadi titik awal sekaligus dasar pemikiran yang memandang bahasa dibentuk melalui gabungan kata-kata, memandang bahasamelalui gabungan kata, kata merupakan satuan terbesar dari bahasa)

(Terjemahan penulis) 
Pendapat Tokieda ini memberikan batasan jelas bahwa satuan bahasa terbesar dan terlengkap adalah teks. Sedangkan penelitian teks dilakukan dengan mendasarkan pada kenyataan kebahasaan bahwa teks sebagai satu kesatuan, sehingga penelitian kebahasaan bidang ini bukan dimulai dari kata sebagai satuan terkecil yang sedikit demi sedikit bergabung dengan kata lain dan membentuk teks secara keseluruhan. Namun penelitian teks dilakukan dengan melihat kenyataan bahwa teks sebagai satu kesatuan makna, karenanya penelitian teks banyak mengangkat permasalahan menyangkut permasalahan bagaimana satuan-satuan pembentuk teks mampu membuat jaring-jaring makna yang akhirnya membentuk satu kesatuan makna teks tersebut.

Tokieda (1950) menekankan bahwa bidang kajian teks mempunyai inti permasalahan pada bagaimana makna-makna yang mengisi konstruksi teks dikembangkan melalui keterkaitan makna atas berbagai kalimat yang membentuk teks tersebut. Karena itu, Tokieda menekankan pada bagaimana teks dibentuk dan dikembangkan sebagai persoalan utama dalam penelitian teks. Sekaligus karakter ini menjadi sudut pandang untuk mengkaji konstruksi teks.

Melanjutkan pemikian Tokieda (1950), Ichikawa (1978) mengkongkritkan pemikiran Tokieda dengan mengajukan konsep-konsep dasar menyangkut permasalahan teks dalam dua hal yakni korelasi dan komposisi/pengaturan unsurunsur pembentuk teks. Kemudian, Ichikawa (1978: ) satuan bahasa dapatdisebut teks atau bukan teks dapat dibedakan atas dua batasan berikut.

(a) teks terdiri atas lebih dari dua kalimat dan masing-masing satuan kalimat tersebut membentuk kepaduan karena adanya kesatuan konteks/makna. (Tougousei)

(b) Tidak terikat atas konteks lain yang mendahului, atau yang mengakiri, namun di dalam teks membentuk kesatuan sendiri. (zentaisei)

\section{Konstruksi Teks Bahasa Jepang}

78 | http://journal.unesa.ac.id/index.php/paramasastra 
Teks sebagai satuan bahasa yang terlengkap dan tertinggi mempunyai struktur yang dikenal dalam bahasa Jepang dengan istilah 'bunshou no kouzou'. Struktur dalam pengertian ini, dipersamakan dengan istilah struktur dalam beberapa kasus seperti mobil, manusia, manupun wilayah yang disebut dengan negara. Masing masing tersebut terdiri atas berbagai unsur yang saling berkaitan membentuk kesatuan yang utuh (Teramura, 1993:11).

Klasifikasi struktur teks bahasa Jepang banyak dikaji dari unsur yang membentuk kesatuan baik frekuensi kemunculan dan letak kemunculannya. Unsur yang membentuk kesatuan teks dikenaldengan istilah 'bunmyaku tenkaikeitai' (periksa Sakuma,2000). Untuk konsep ini akan dijelaskan secara detail pada subbab berikutnya.

Sakuma (2000) menekankan pada unsur pembentuk kesatuan teks yang berbentuk satuan kalimat maupun paragraf yang dikenal dengan kalimat pokok/paragraf pokok. Sakuma mengklasifikasikan teks bahasa Jepang berdasar pada frekuensi kemunculan dan letak kemunculan, serta daya perekat untuk menyatukan berbagai unsur pembentuk teks dalam enam kategori.

1. Toukatsugata 'teks berjenis ini berkarakter kalimat/paragraf pokok berada pada bagian pendahuluan teks'

2. Bikatsugata 'teks berjenis ini berkarakter kalimat/paragraf pokok berada pada bagian akhir teks'

3. Chukatsugata 'teks berjenis ini berkarakter kalimat/paragraf pokok berada pada dua bagian tengah teks'

4. Ryoukatsugata 'teks berjenis ini berkarakter kalimat/paragraf pokok berada pada dua bagian pada teks misalnya bagian pendahuluan dan akhir teks'

5. Bunkatsugata 'teks berjenis ini berkarakter kalimat/paragraf pokok berada pada tiga bagian yakni pada bagian pendahuluan, tengah dan akhir teks'

6. Senkatsugata 'teks berjenis ini berkarakter kalimat/paragraf pokok tidak bisa dideteksi secara pasti dan tersembunyi’ 
Pembagian konstruksi teks bahasa Jepang menurut Sakuma sebenarnya merupakan pengembangan pemikiran Ichikawa (1978) dan Nagano (1986) yang masing-masing sama-sama mengajukan konsep kesatuan teks 'toukatsusei'. Namun demikian, klasifikasi Sakuma menjadi klasifikasi yang rinci dari pemikiran-pemikiran sebelumnya sehingga banyak penelitian-penelitian yang datang kemudian banyak merujuk Sakuma. Memang tidak bisa dipungkiri bahwa klasifikasi struktur teks bahasa Jepang Sakuma masih bersifat umum dan mengindahkan karakteristik genre teks yang dipakai dalam analisisnya dan analisis struktur teks secara makro. Oleh karena itu, penelitian ini hadir dalam usaha untuk mengembangkan pemikiran Sakuma dengan mengangkat objek penelitian berupa teks dalam genre faktual baik dalam jenis teks deskripsi, laporan, berita maupun argumentatif sebagai hasil dari karangan mahasiswa. Selain itu, analisis struktur teks dilakukan dalam dua sudut pandang berupa analisis mikro yang menekankan hubungan antarkalimat atau antarparagraf, dan analisis secara makro dengan mendasarkan pada peletakan kalimat/paragraf pokok.

\section{Unsur Pembentuk Teks}

Teks sebagai satuan tertinggi dan terlengkap dalam kajian bahasa terbentuk dari berbagai unsur yang saling berkait dan membentuk kesatuan 'toukatsuei'. Alat pembentuk kesatuan 'toukatsusei' teks dikenal dengan istilah bunmyakutenkai keitai.

Sakuma(2000) menyebut dan memerinci bentuk-bentuk yang mampu membuat kesatuan makna dalam teks dalam klasifikasi berikut.

1. Setsuzoku Hyougen "bentuk-bentuk sambung"

2. Shiji hyougen " bentuk-bentuk penunjukan"

3. Hanpuku Hyougen " bentuk-bentuk pengulangan”

4. Shouryaku hyougen "bentuk-bentuk pemendekan/elipsis"

5. Teidai Hyougen " bentuk-bentuk penanda tema"

80 | http://journal.unesa.ac.id/index.php/paramasastra 
6. Jojutsu Hyougen "bentuk-bentuk penanda rema"

Pendapat Sakuma di atas mengajukan bentuk-bentuk pembentuk kesatuan makna teks secara umumdalam bahasa Jepang. Selain bentuk-bentuk ini, Nita.et.all (2009) mengajukan bentuk-bentuk lain seperti bentuk berpasangan, hubungan pertanyaan-jawaban dapat diklasifikasikan sebagai bentuk-bentuk yang mampu membuat teks atau wacana memiliki kesatuan makna secara kuat.

Penelitian ini hanya akan memokuskan pada dua bentuk yakni bentuk-bentuk penyambung dan bentuk-bentuk pengulangan dalam teks karangan mahasiswa. Penguraian karakteristik kontsruksi teks melalui penyelidikan kohesi berupa bentuk penyambung antarkalimat/antarparagraf dalam penelitian ini dimaknai dengan analisis konstruksi teks secara mikro. Sedangkan analisis konstruksi teks secara makro dimaknai bahwa penguraian konstruksi teks melalui pencarian kalimat/paragraf pokok untuk mengkategorisasikan konstruksi teks yang bersangkutan.

Maynard (2005) mengidentifikasi bahwa konstruksi teks bahasa Jepang dapat dibedakan atas tiga bagian besar dalam istilah hajime, naka dan owari. Istilah lain yang dipakai untuk menunjuk tiga bagian tersebut misalnya joron, honron dan ketsuron. Sedangkan ahli yang lain ada yang membagi konsstruksi teks bahasa Jepang dalam empat bagian yakni ki, shou, ten dan ketsu, sering disebut dalam istilah "kishoutenketsu".

Penelitian baik yang dilakukan Sakuma (2000) maupun Meynard (2005) masih bersifat sangat umum. Klasifikasi-klasifikasi tersebut masih membutuhkan penjelasan detail mengenai karakter-karakter pengisi bagian-bagian tersebut sebagai ciri khas teks bahasa Jepang. Karena itu, penelitian lanjutan untuk memerinci karakter-karakter tersebut sangat diperlukan. Penelitian ini dilakukan dalam usaha melanjutkan pemikiran-pemikiran dan penyelidikan yang sudah dilakukan oleh para peneliti seperti Sakuma (2000), Meynard (2005) melalui sudut pandang yang lain untuk mendapatkan pemahaman yang lengkap mengenai karakteristik konstruksi teks bahasa Jepang. 


\section{Kata Sambung dan Kalimat Pokok (Tinjauan Singkat)}

Kata sambung dalam penelitian teks bahasa Jepang dikenal dengan beragam istilah seperti setsuzokushi, setsuzokugoku, setsuzoku hyougen. Banyak Para ahli linguistik bahasa Jepang menggunakan istilah yang beragam untuk membedakan antara istilah satu dengan lainnya khususnya menyangkut batasan-batasan pada masing-masing istilah yang bersangkutan. Istilah yang disebutkan diawal lebih spesifik dan terbatas bila dibandingkan dengan istilah yang disebutkan belakangan. Misalnya, setsuzoku hyougen mencakup setsuzokushi (kata sambung) serta kata jenis lain (selain kata sambung) yang mempunyai fungsi yang sama dengan kata sambung (periksa Sakuma 1990).

Ichikawa (1978:89-90) dan Sakuma (1990:19) mengajukan klasifikasi kata sambung antarkalimat dalam delapan kategori. Secara singkat kedelapan kategori tersebut akan disimpulkan dalam uraian berikut.

1. Junsetsugata; merupakan kata sambung antarkalimat ketika kalimat pertama sebagai sebab, alasan atas akibat yang akan diungkapkan pada kalimat keduanya. Jenis kata sambungnya seperti dakara, desukara, shitagatte, sono tame.

2. Gyakusetsugata; merupakan kata sambung antarkalimat ketika pernyataan atau isi kalimat sebelumnya bertentangan dengan pernyataan atau isi kalimat sesudahnya. Jenis kata sambungnya seperti shikashi, keredomo, daga, demo, ga.

3. Tenkagata; merupakan kata sambung antarkalimat ketika kalimat kedua menambahkan maknanya pada kalimat sebelumnya. kata sambung seperti soshite, sorekara, mata, sara ni merupakan kelompok ini.

4. Taihigata; merupakan kata sambung antarkalimat untuk membandingkan isi atau makna kalimat pertama dan kalimat berikutnya. Jenis kata sambungnya seperti ippou-tahou, gyakuni, kaette, mata wa.

82 | http://journal.unesa.ac.id/index.php/paramasastra 
5. Tenkangata; merupakan kata sambung untuk mengalihkan topik pembicaraan yang berbeda dalam komunikasi. Dalam bahasa Jepang mengenal kata sambung seperti tokoro de, sate, sore dewa merupakan jenis klasifikasi ini.

6. Douretsugata; merupakan kata sambung yang menghubungkan dua kalimat yang makna atau isinya dianggap sama. Kata sambung jenis ini seperti sunawachi, tsumari, tatoeba, toku ni.

7. Hosokugata; merupakan kata sambung antarkalimat yang mana kalimat kedua melengkapi makna atau isi kalimat pertama. Kata sambung jenis ini seperti nazenara, nao, chinami ni.

8. Rensagata; merupakan bentuk penyambungan antarkalimat dengan tidak menggunakan kata sambung. Klasifikasi ini merupakan realisasi dari bentuk koherensi teks melalui hubungan implisit seperti hubungan antara pertanyaan dan jawaban, latar dan simpulan, penjelasan dan pernyataan sikap/pendapat.

Klasifikasi bentuk penyambung antarkalimat ini sangat jelas dan rinci menyangkut batasan dan konsep masing-masing. Klasifikasi ini akan digunakan untuk menganalisis permasalahan pertama dalam analisis.

Selanjutnya pembahasan dilanjutkan pada permasalahan kalimat atau paragraf pokok dalam konstruksi teks bahasa Jepang. Uraian berikut merupakan hasil penelusuran kepustakaan terkait kalimat atau paragraf pokok yang dikenal dalam istilah bahasa Jepang 'shudaibun' atau 'shudai danraku'.

Sakuma (1995:107) menekankan ciri khas kalimat pokok dalam teks bahasa Jepang yakni kalimat pokok biasanya berkonstruksi lengkap dengan topik dan komen, isinya menyatakan simpulan atau ringkasan topik pembicaraan teks, dan letaknya biasanya di bagian akhir atau hadir bersama-sama pada awal dan akhir teks.

Sunagawa (2000) menyelidiki teks eksposisi untuk menentukan kalimat pokok melalui sudut pandang pengulangan judul teks baik menyangkut frekuensi kemunculan maupun penyebaran dari masing-masing kata pembentuk judul teks 
dalam tubuh teks yang bersangkutan. Pendapat Sunagawa (2000) ini sebenarnya sudah pernah dilakukan oleh Shiozawa (1994) dan Nurhadi (2013) yang menekankan pentingnya judul untuk menentukan letak kalimat pokok, serta berdasarkan pada letak kalimat pokok tersebut membuat klasifikasi teks argumentatif bahasa Jepang.

Berdasarkan pada pendapat dan hasil pemeriksaan kepustakaan tersebut, penelitian ini mengambil sudut pandang yang sama untuk menentukan kalimat pokok dengan mendasarkan pada pengulangan judul teks. Berdasarkan pada letak pengulangan judul dalam tubuh teks, konstruksi karangan mahasiswa angkatan 2013 akan diklasifikasikan. Selain itu, bersama dengan analisis kalimat pokok, penelitian ini juga akan mengklasifikasikan judul karangan mahasiswa berdasarkan pada aspek bentuk atau komposisinya.

\section{HASIL DAN PEMBAHASAN}

Hasil analisis terhadap permasalahan pertama dalam latar belakang akan dideskripsikan dalam uraian berikut. Hasil pemeriksaan bentuk kohesi berupa kata sambung dan penyelidikan keberadaan kalimat/paragraf pokok akan dideskripsikan berikut.

\section{Bentuk Kata Sambung Antarkalimat atau Antarparagraf}

Kohesi berupa kata sambung yang menjadi objek penelitian ini dibatasi hanya merujuk pada kohesi berupa kata sambung antarkalimat atau antarparagraf dalam teks karangan mahasiswa. Penelitian ini tidak memasukan sebagai bagian analisis untuk kata sambung di dalam kalimat, atau jenis kata tertentu yang mempunyai fungsi seperti kata sambung (dalam istilah umum disebut dengan kata bantukata sambung 'setsuzoku joshi)'

Penggunaan kata sambung dalam karangan mahasiswa angkatan 2013 Unesa dapat digambarkan dalam tabe 1 berikut.

Tabel 1Kata Sambung Antarkalimat maupun Antarparagraf 


\begin{tabular}{|c|c|c|c|c|c|c|c|c|c|c|}
\hline \multirow[t]{2}{*}{ No } & \multirow[t]{2}{*}{ Bentuk } & \multicolumn{8}{|c|}{ Tema Karangan } & \multirow[t]{2}{*}{ Total } \\
\hline & & 1 & 2 & 3 & 4 & 5 & 6 & 7 & 8 & \\
\hline $\mathbf{1}$ & Soshite & 12 & 9 & 22 & 28 & 7 & 7 & 2 & 8 & 95 \\
\hline 2 & Sorekara & 2 & 3 & 5 & 5 & & 1 & & 2 & 18 \\
\hline 3 & De & & & & & & & & 1 & 1 \\
\hline 4 & Mata & & 1 & & 4 & & & 1 & & 6 \\
\hline 5 & Sara ni & & 1 & & & & & & 1 & 2 \\
\hline 6 & Sono ue & & 1 & & & & & & & 1 \\
\hline 7 & Ato de & & & 1 & & & & & & 1 \\
\hline 8 & Tatoeba & 4 & 4 & 9 & 29 & 3 & 9 & 5 & 8 & 71 \\
\hline 9 & Toku ni & 1 & 1 & 1 & & 2 & & & 1 & 6 \\
\hline 10 & Sorede & 3 & 2 & 4 & 1 & & & & 4 & 14 \\
\hline 11 & Sono ato & 2 & & & & & & & & 2 \\
\hline 12 & Soreni & 6 & 3 & 2 & 5 & 1 & 5 & & 4 & 26 \\
\hline 13 & Shikamo & & & & & & & & 1 & 1 \\
\hline 14 & Desu kara & 8 & 4 & 3 & 5 & & 1 & & 6 & 27 \\
\hline 15 & Da kara & 6 & 5 & 12 & 12 & & & 4 & 8 & 47 \\
\hline 16 & Sono tame & 2 & 1 & & & & & & & 3 \\
\hline 17 & $\begin{array}{l}\text { Soiu koto } \\
\text { kara }\end{array}$ & 1 & & & & & & & & 1 \\
\hline 18 & Shitagatte & & & & & & & & 1 & 1 \\
\hline 19 & Sou ieba & 1 & & & & & & & & 1 \\
\hline 20 & Suruto & & & 1 & & & & & 1 & 2 \\
\hline 21 & Shikasi & 7 & 6 & 2 & 8 & & 1 & & 2 & 26 \\
\hline 22 & Demo & 11 & 8 & 18 & 22 & 1 & 4 & 5 & 8 & 77 \\
\hline 23 & Desu ga & & 1 & 1 & & & & & 6 & 8 \\
\hline 24 & Dakedo & & 1 & & & & & & & 1 \\
\hline 25 & Da ga & & 1 & & & & & & 1 & 2 \\
\hline 26 & Keredomo & & & & & & & & 3 & 3 \\
\hline 27 & Tonikaku & & & & & & & & 1 & 1 \\
\hline 28 & $\begin{array}{l}\text { Kore } \\
\text { taishite }\end{array}$ & & 1 & & & & & & & 1 \\
\hline 29 & Mata wa & 1 & & 1 & 1 & & & & & 3 \\
\hline 30 & Yahari & & 1 & & & & & & & 1 \\
\hline 31 & Tsumari & & 1 & & & & & & 1 & 2 \\
\hline
\end{tabular}




\begin{tabular}{|c|c|c|c|c|c|c|c|c|c|c|}
\hline 32 & Naze nara & 1 & 3 & & 3 & & & & 4 & 11 \\
\hline 33 & Nazeka toiuto & 3 & 1 & & & & & & 1 & 5 \\
\hline 34 & Tokorode & & 1 & & 1 & 11 & 9 & & 1 & 23 \\
\hline 35 & $\begin{array}{l}\text { Soredewa/de } \\
\text { wa }\end{array}$ & & & & 1 & & & & 1 & 2 \\
\hline 36 & Somosomo & & & & & & & & 1 & 1 \\
\hline 37 & Mazu/saisho & & & & & & & & 3 & 3 \\
\hline 38 & Saigo & & & & & & & & 1 & 1 \\
\hline & Total & 71 & 60 & 82 & 125 & 25 & 37 & 17 & 80 & 497 \\
\hline
\end{tabular}

\# 1.Kodomo no yume 2.Tanoshikatta koto kanashikatta koto3. Hon no rebiu

4. Nihongo o benkyoushite wakatta koto5. Meiru de nihonjin to yaritori suru (jikoshoukai)6. meiru de indonesia no koto wo shoukai suru7. Posutaa 8. Obento ni Tsuite

Hasil mencermati teks karangan mahasiswa Prodi Pendidikan Bahasa Jepang angkatan 2013 yang berjumlah 22 mahasiswa terkait kohesi berupa bentuk penyambung kalimat atau paragraf dalam karangan mahasiswa beserta frekuensi pemakaiannya dalam karangan seperti pada tabel 1 di atas. Hasil analisis dalam tabel ini dapat dideskripsikan secara ringkas dalam uraian berikut.

Dalam teks karangan mahasiswa, jenis kata sambung yang digunakan berjumlah 38 jenis dengan penyebaran dan frekuensi penggunaan seperti dalam tabel 1. Masing-masing 38 jenis kata sambung ini dapat diklasifikasikan dalam delapan kelompok kata sambung berdasarkan kemiripan fungsi atau makna masing-masing kata sambung tersebut dalam menyambungkan antarkalimat atau antarparagraf. Kedelapan klasifikasi kata sambung ditunjukkan berbeda melalui pembubuan warna dalam tabel 1 untuk membedakan jenis satu dengan lainnya.

Merujuk pada klasifikasi kata sambung oleh Ichikawa (1978), Sakuma (1990) tujuh kelompok kata sambung yang digunakan dalam teks karangan mahasiswa Prodi Pendidikan Bahasa Jepang Unesa yakni; 1. Tenkagata (penambahan) - dalam tabel 1 ditunjukkan dalam nomor 1 sampai 13; 2 . Junsetsugata (sebab-akibat) - dalam tabel 1 ditunjukkan dalam nomor 14 sampai 20; 3. Gyakusetsugata (pertentangan) - dalam tabel 1 ditunjukkan dalam nomor

\section{6 | http://journal.unesa.ac.id/index.php/paramasastra}


21 sampai 27; 4. Taihigata (perbandingan) - dalam tabel ditunjukkan dalam nomer 28 dan 29; 5. Doretsugata (pengulangan) - dalam tabel tunjukkan dalam nomor 30 dan 31; 6. Hosokugata (pelengkapan) - dalam tabel ditunjukkan dalam nomor 32 dan 33; 7. Tenkangata (peralihan topik) dalam tabel ditunjukkan dalam nomor 34 sampai 36; 8. Junbangata (pengurutan) - dalam tabel ditunjukkan dalam 37 dan 38.

Secara rinci dapat di simpulkan di sini bahwa, teks karangan mahasiswa angkatan 2013 Prodi Pendidikan bahasa Jepang banyak menggunakan kata sambung jenis tenkagata (penambahan) sebanyak $49 \%$ dari persentase penggunaan kata sambung secara keseluruhan. Secara spesifikuntuk kata sambung jenis tenkagata, penggunaan kata soshite menjadi kata sambung terbanyak dipakai, dalam karangan mahasiswa frekuensi penggunaan sebanyak 95 kali dari 244 penggunaan $(39 \%)$. Setelah soshite, kata sambung tatoeba dipakai sebanyak 71 kali dari 244 penggunaan (29\%). Selajutnya secara berturut-turut ungkapan yang banyak digunakan yakni soreni $(11 \%)$, sorekara $(7 \%)$ dan sorede $(6 \%)$. Sedangkan kata sambung seperti mata, tokuni, shikamo dan lain-lainnya dipakai mahasiswa untuk menyambung kalimat atau paragraf yang bermakna menambah informasi atau isi pada kalimat atau paragraf sebelumnya dengan frekuensi pemakaian yang tidak terlalu banyak.

Hasil analisis atas penggunaan kata sambung jenis tenkagata yang banyak dipakai dalam karangan mahasiswa angkatan 2013 Unesa tidak bisa dilepaskan dari waktu pengenalan atau masa pembelajaran kata sambung jenis ini

Jenis bentuk kata sambung terbanyak yang kedua dipakai dalam karangan mahasiswa yakni kelompok gyakusetsugata 'pertentangan'. Penggunaan kata sambung jenis gyakusetsugata sebanyak 24\%. Pengisi terbanyak dalam klasifikasi ini oleh kata demo dengan persentase penggunaan sebanyak 65\%. Setelah kata demo, urutan kedua ada kata shikashi dengan persentase penggunaan $22 \%$. Kemudian disusul berturut-turut desu ga (8\%), keredomo (3\%), da ga (2\%), 
dakedo (1\%), dan tonikaku (1\%). Akan tetapi hasil ini menandai bahwa pemahaman mahasiswa mengenai penggunaan kata sambung jenis gyakusetsu dengan kesesuaian ragam kalimat perlu dilihat kembali. Hal ini disebabkan karena penggunaan kata sambung demo kurang tepat mengingat ragam bahasa (kalimat) dalam karangan mahasiswa bersifat formal dengan penggunaan kalimat yang bercirikan bentuk sopan 'teineikei'. Seperti yang dipahami bahwa kata sambung demo sering diimplementasikan dalam percakapan dengan teman sebaya atau seseorang yang mempunyai kedudukan yang lebih rendah misalnya hubungan senior-yunior, kakak-adik, antarteman di sekolah.

Tabel 1 di atas, menunjukkan bahwa klasifikasi kata sambung jenis junsetsugata banyak dipakai dalam karangan mahasiswa Unesa. Junsetsugata merupakan jenis kata sambung yang menunjukkan hubungan sebab-akibat. Persentase penggunaan kata sambung jenis ini sebanyak 17\%. Penggunaan junsetsugata dalam karangan mahasiswa tidak terlalu banyak jumlahnya bila dibandingkan dengan dua jenis kata sambung yang sudah dijelaskan lebih awal dalam subbab ini. Terutama kata desu kara dan da kara masing-masing mempunyai persentase $57 \%$ untukdesu kara dan $33 \%$ untuk dakaradari penggunaan jenis junsetsugata seluruhnya. Junsetsugata dipakai untuk menunjukkan hubungan kelogisan (sebab-akibat) dari dua pernyataan yang dihubungkan, atau hubungan antarparagraf yang berkaitan karena hubungan latarpenjelasan, atau hubungan prasyarat-tujuan/sasaran yang dituju. Pemakaian kata sambung jenis junsetsugata khususnya kata desukara dan dakara menjadi pilihan mahasiswa dalam karangannya tidak terlepas kedua kata ini yang memang sejak pembelajaran tingkat awal sudah dikenalkan. Hanya permasalahan dari penggunaan kata sambung junsetsugata, mahasiswa belum memahami dengan baik penggunaan kata sambung dakara. Dakara hanya digunakan untuk komunikasi verbal antarteman, nonformal dan tidak bisa dipakai untuk bahasa tulis atau situasi formal.

88 | http://journal.unesa.ac.id/index.php/paramasastra 
Klasifikasi kata sambung berikutnya yang digunakan dalam karangan mahasiswa yakni jenis peralihan topik pembicaraan yang diimplementasikan dalam karangan dengan kata sambung seperti tokorode, soredewa/dewa, dan somo somo. Tokorode banyak menjadi pilihan mahasiswa untuk menyatakan peralihan topik dalam karangan, dalam hasil penyelidikan sebanyak 23 (88\%) pemakaian dari keseluruhan penggunaan kata sambung jenis tenkangata. Sedangkan soredewa/dewa dan somo somo tidak banyak muncul dalam karangan mahasiswa. Asumsi yang bisa diajukan karena selain kedua kata ini penggunaannya sangat spesifik dalam bahasa Jepang

Jenis bentuk kata sambung selanjutnya yang digunakan mahasiswa Unesa yakni hosokugata (pelengkapan) dengan persentase sebanyak 3\%. Bentuk kata sambung yang digunakan mahasiswa hanya ditemukan dua jenis yakni naze nara (11) dan naze ka toiuto (5). Fungsi kata sambung jenis ini yakni menambah atau melengkapi informasi yang sudah dinyatakan dalam kalimat sebelumnya dengan menghubungkannya melalui penambahan alasan atau penyebab atas pokok permasalahan dalam pernyataan sebelumnya. Pernyataan sebelumnya diposisikan sebagai keadaan atau hasil dari kegiatan yang memerlukan penjelasan alasan atau hal yang mendasari keadaan atau hasil kegiatan tersebut terjadi.

Klasifikasi dari bentuk kata sambung yang ada dalam karangan mahasiswa Unesa yakni junbangata 'pengurutan' sebanyak 4(1\%) pemakaian, taihigata 'perbandingan' sebanyak 4(1\%)pemakaian, dan douretsugata 'pengulangan' sebanyak 3(0.6\%) pemakaian. Klasifikasi tersebut memang tidak terlalu banyak dipakai dalam karangan mahasiswa. Hal ini disebabkan karena belum banyak mahasiswa yang memahami kata sambung jenis ini secara baik mengingat pengenalan masing-masing kata sambung ini dalam level bahasa Jepang tingkat menengah atas. Banyak mahasiswa yang belum mengetahui kata sambung jenis disebabkan materi dalam buku pegangan mahasiswa belum mengenalkan kata sambung jenis ini dengan porsi memadai layaknya kata sambung lainnya yang 
sudah dikenalkan pada bagin awal pembelajaran.Namun sebagai simpulan dari hasil di atas dapat disebutkan bahwa penggunaan variasi bentuk kata sambung dalam karangan mahasiswa dapat disebutkan beragam jenis dan tidak terkesan monoton. Hanya beberapa jenis kata sambung belum banyak digunakan selain faktor pengenalan kata sambung yang bersangkutan belum banyak dimasukkan dalam materi juga disebabkan karena tema pokok dalam karangan yang digunakan dalam penelitian ini terbatas, akibatnya sedikit-banyak mempengaruhi penggunaan kata sambung yang sesuia dengan konteks tema karangan.

\section{Klasifikasi Judul Karangan}

Permasalahan kedua yang akan dideskripsikan di sini yakni bagaimana bentuk dan klasifikasi judul karangan mahasiswa angkatan 2013 Unesa. Mendasarkan pada klasifikasi Goto (1998), Hasil analisis klasifikasi judul karangan dapat disimpulkan dalam tabel 2 berikut ini.

Tabel 2 Klasifikasi bentuk Judul Karangan

\begin{tabular}{|c|c|c|c|c|c|c|c|c|c|c|}
\hline \multirow{2}{*}{$\begin{array}{l}\mathbf{N} \\
\mathbf{o}\end{array}$} & \multirow{2}{*}{$\begin{array}{l}\text { Klasifikasi } \\
\text { bentuk judul }\end{array}$} & \multicolumn{8}{|c|}{ Tema Karangan } & \multirow[b]{2}{*}{ Total } \\
\hline & & 1 & 2 & 3 & 4 & 5 & 6 & 7 & 8 & \\
\hline 1 & $\begin{array}{l}\text { Shuushikei } \\
\text { jutsubu }\end{array}$ & 2 & - & 2 & 5 & - & - & 2 & 3 & 14 \\
\hline 2 & Taigen dome & 16 & 9 & 15 & 14 & - & - & 20 & 17 & 91 \\
\hline 3 & $\begin{array}{ll}\text { Jutsubu } & \text { no } \\
\text { shouryaku } & \end{array}$ & - & 4 & - & 3 & - & - & - & 1 & 8 \\
\hline \multirow[t]{2}{*}{4} & $\begin{array}{l}\text { Midashibun } \\
\text { nashi }\end{array}$ & 2 & 9 & 5 & - & - & - & - & 1 & 17 \\
\hline & & 20 & 22 & 22 & 22 & - & - & 22 & 22 & 130 \\
\hline
\end{tabular}

Hasil analisis bentuk judul karangan berdasarkan pada pemeriksaan bentuk ungkapan dalam judul karangan didapatkan simpulan bahwa klasifikasi atas judul dengan jenis taigen dome jutsubu 'kata atau frase kata benda mendominasi dengan jumlah 91(70\%) dari 130 karangan. Terbanyak kedua jenis midashibun nashi 90 | http://journal.unesa.ac.id/index.php/paramasastra 
'tidak berjudul' sebanyak 17(13\%) karangan. Sedangkan jenis shuushikei jutsubu 'berakhir dengan predikatif kata kerja' sebanyak 14(11\%) karangan dan jutsubu no shouryaku 'elipsis predikat kata kerja' sebanyak8(6\%) karangan.Pemahaman bahwa judul merupakan frase kata benda sudah dipahami oleh mahasiswa sehingga sebagian besar judul berupa frase kata benda. Pemahaman ini juga tidak terlepas dari pembelajaran dalam bahasa Ibu pembelajar yang memang dipahami bahwa judul berupa frase kata benda.

Penyelidikan selanjutnya difokuskan pada masalahklasifikasi teks karangan mahasiswa terkait peletakan kalimat pokok jika dilihat dari sudut pandang pengulangan judul karangan. Hasil penyelidikan pada masing-masing karangan dapat disimpulkan dalam tabel 3 berikut.

Tabel 3 Klasifikasi Teks berdasarkan frekuensi dan letak Peletakan Kalimat Pokok

\begin{tabular}{|c|c|c|c|c|c|c|c|c|c|c|}
\hline \multirow[t]{2}{*}{ No } & \multirow{2}{*}{$\begin{array}{l}\text { Klasifikasi } \\
\text { bentuk judul }\end{array}$} & \multicolumn{8}{|c|}{ Tema Karangan } & \multirow[b]{2}{*}{ Total } \\
\hline & & 1 & 2 & 3 & 4 & 5 & 6 & 7 & 8 & \\
\hline 1 & $\begin{array}{l}\text { Kaishibu } \\
\text { hanpuku gata }\end{array}$ & 10 & 4 & 10 & 8 & - & - & 6 & 7 & $\begin{array}{l}45(35 \\
)\end{array}$ \\
\hline 2 & $\begin{array}{l}\text { Chuukanbu } \\
\text { hanpukugata }\end{array}$ & 2 & 3 & - & 2 & - & - & - & 3 & $10(8)$ \\
\hline 3 & $\begin{array}{l}\text { Shuuryoubu } \\
\text { hanpukugata }\end{array}$ & 4 & 3 & 3 & 1 & - & - & 1 & 2 & )$^{14(10}$ \\
\hline 4 & $\begin{array}{l}\text { Ryoubu } \\
\text { hanpukugata }\end{array}$ & 1 & 3 & 1 & 8 & - & - & 7 & 5 & $\begin{array}{l}25(20 \\
)\end{array}$ \\
\hline 5 & $\begin{array}{l}\text { Hihanpukugat } \\
\text { a }\end{array}$ & 3 & 9 & 8 & 3 & - & - & 6 & 5 & $\begin{array}{l}34(27 \\
)\end{array}$ \\
\hline & Total & 20 & 22 & 22 & 22 & & & 20 & 22 & 128 \\
\hline
\end{tabular}

Hasil penyelidikan dalam tabel 3 menunjukan bahwa teks jenis kaishibu hanpukugata 'teks dengan kalimat pokok pada bagian pendahuluan' merupakan jenis yang sering dipilih mahasiswa dalam pembelajaran sakubun angkatan 2013 
Unesa. 45 karangan mahasiswa dari 128 karangan yang menjadi objek penelitian, atau 35\% karangan mahasiswa angkatan 2013 Unesa, bagian pendahuluannya memuat kalimat pokok.Selanjutnya, teks jenis hihanpukugata 'teks dengan tidak mengalami pengulangan pada judulnya' jumlahnya cukup banyak $27 \%$. Hal ini disebabkan oleh salah satu alasannya yakni pada beberapa karangan tidak terdapat judul yang secara tidak langsung menambah dalam jumlah persentase pada klasifikasi ini.

Sedangkan hasil klasifikasi atas teks jenis ryoubu hanpukugata sebanyak $20 \%$. Ryoubu hanpukugata 'teks dengan struktur kalimat pokok diulang pada dua atau lebih bagian dalam teks' memang cukup banyak jumlahnya khususnya pengulangan judul pada beberapa bagian dalam teks untuk mempertegas sebagai ide yang ingin disampaikan. Namun jika lebih dicermati lebih mendalam, pengulangan kalimat pokok pada beberapa bagian teks tersebut dapat diklasifikasikan dan disimpulkan bahwa pengulangan lebih banyak dilakukan di awal teks. Sehingga bila simpulkan bahwa pengulangan jenis kaishibu hanpukugata 'pengulangan pada bagian pendahuluan teks' jumlahnya akan lebih banyak lagi. Sebagai kebalikan dari klasifikasi ini, teks dengan jenis shuryoubu hanpukugata 'teks dengan pengulangan kalimat pokok pada bagian penutup' sebanyak 10\% dalam karangan mahasiswa angkatan 2013 Unesa. Secara umu, hasil klasifikasi atas teks karangan mahasiswa Unesa dapat disimpulkan bahwa kalimat pokok dalam teks lebih sering dimunculkan atau diulang pada bagian awal teks untuk mendasari penjelasan-penjelasan tentang topik yang akan ditampilkan pada bagian-bagian selanjutnya. Hasil ini menjadi kebalikan dari teks bahasa Jepang yang lebih sering memunculkan atau mengulang kalimat pokok dalam bagian akhir teks sebagai sesuatu yang ingin disampaikan dalam teks yang bersangkutan.

\section{Pembahasan}

92 | http://journal.unesa.ac.id/index.php/paramasastra 
Analisis pada karangan mahasiswa melalui pendeteksian bentuk kata sambung yang digunakan serta kategorisasi teks mendasarkan pada peletakan kalimat atau paragraf pokok. Khusus untuk analisis kalimat atau paragraf pokok digunakan judul sebagai tolok ukur mendeteksi kalimat pokok atau paragraf pokok. Judul karangan dalam penelitian ini didefinikan sebagai simpulan teks sebagai cerminan bagian yang ditonjolkan atau bagian yang ingin disampaikan dalam karangan. Sudut pandang ini banyak digunakan dalam beberapa penelitian struktur teks dalam bahasa Jepang semisal Gotou (1998), Li (2000), Nurhadi (2013). Beberapa penelitian ini menguji pandangan tentang fungsi judul dalam karangan serta penerapan pandangan tersebut dalam mengklasifikasikan struktur teks bahasa Jepang.

Hasil analisis terhadap penggunaan kata sambung dan frekuensi kemunculannya sudah dijelaskan seperti dalam uraian sebelumnya. Mendasarkan pada hasil tersebut, pembahasan dalam subbab ini mencermati tentang beberapa hal terkait karakteristik struktur karangan mahasiswa Unesa khususnya berkaitan dengan bentuk penyambung antar kalimat atau antar paragraf dan klasifikasi teks. Sudut pandang ini berkaitan dengan pengembangan topik dan kesatuan makna dalam teks sebagai masalah utama dalam penelitian teks dalam bahasa Jepang.

Pertama, bentuk kata sambung yang aktif dipakai dalam karangan mahasiswa yakni tenkagata 'penambahan/penambalan' informasi atas kalimat sebelumnya. Dalam jenis ini kata sambung seperti soshite, tatoeba, soreni, sorekara, dan sorede secara berurutan menjadi banyak dipakai secara aktif untuk menyambungkan kalimat atau paragraf dalam bahasa Jepang. Isi informasi yang disambungkan melalui kata sambung tersebut berkaitan dengan penambahan atau penjelasan tambahan untuk memperjelas, menambah, dan menguraikan informasi sebelumnya sehingga menghasilkan pengembangan topik secara linier. Penggunaan banyak kata sambung jenis tenkagata memang tidak bisa dilepaskan dari genre teks yang menjadi objek penelitian ini. penelitian teks karangan 
mahasiswa yang dianalisis disadari lebih banyak teks yang ber-genre deskriptif dan ekspositori, hanya satu teks yang ber-genre argumentatif. Penelitian ini memang tidak membedakan atas genre untuk melihat bentuk kata sambung yang digunakan sehingga pada penelitian ini tidak bisa mengajukan simpulan pada masalah tersebut. Namun, penggunaan kata sambung jenis tenkagatabanyak dipakai dalam karangan mahasiswa untuk memperjelas dan menambah informasi, serta dapat disebutkan bahwa frekuensi penggunaan kata sambung jenis tenkagata diindikasikan terdapat keterkaitan dengan teks bergenre deskriptif dan ekspositori. Selain itu, frekuensi penggunaan kata sambung jenis ini tidak lepas dari pengenalan bentuk kata sambung ini yang sudah dikenalkan sejak awal pembelajaran. Sehingga mahasiswa sangat kenal dengan baik penggunaan kata sambung jenis ini.

Kedua, berkaitan dengan hasil penyelidikan atas klasifikasi teks berdasarkan peletakan kalimat atau paragraf pokok didapatkan hasil bahwa teks dengan jenis peletakan kalimat atau paragraf pokok di awal teks 'kaishibu hanpukugata'. Berdasarkan pada hasil ini, penulis mengajukan simpulan bahwa kalimat pokok merupakan topik utama dalam karangan yang mendasari pengembangan topik-topik yang mengoonstruk teks yang bersangkutan. Karena itu, kehadiran kalimat atau paragraf pokok dimunculkan di awal teks dan mengilhami bagian-bagian selanjutnya dalam teks. Selain itu, karakteristik retorika pembelajar bahasa Jepang dari Indonesia lebih memilih mengajuan pernyataan berupa pendapat, pesan, anjuran sebagai simpulan atau bagian yang ingin ditonjolkan dalam teks dimunculkan lebih awal. Retorika orang Indonesia lebih menyukai mengajukan pendapat dulu baru disusul dengan pernyataan berupa fakta, kenyataan dan bukti-bukti yang mendukung setelahnya. Bentuk retorika seperti ini berlawanan dengan retorika orang Jepang dalam mengajukan pendapat atau pembahasan persoalan tertentu dalam komunikasi bentuk tulisan.

94 | http://journal.unesa.ac.id/index.php/paramasastra 


\section{SIMPULAN}

Klasifikasi kata sambung yang digunakan berjumlah 38 jenis dengan penyebaran dan frekuensi penggunaan dalam karangan mahasiswa Unesa dapat dibedakan menjadi 38 jenis kata sambung, serta dapat diklasifikasikan dalam delapan kelompok kata sambung berdasarkan kemiripan fungsi atau makna. Kedelapan kelompok kata sambung itu dibedakan atas 1. Tenkagata (penambahan); 2. Junsetsugata (sebab-akibat); 3. Gyakusetsugata (pertentangan); 4. Taihigata (perbandingan); 5. Doretsugata (pengulangan); 6. Hosokugata (pelengkapan); 7. Tenkangata (peralihan topik); 8. Junbangata (pengurutan).

Hasil analisis bentuk judul karangan berdasarkan pada pemeriksaan bentuk ungkapan dalam judul karangan didapatkan simpulan bahwa klasifikasi atas judul dengan jenis taigen dome jutsubu 'kata atau frase kata benda mendominasi dengan jumlah 91(70\%) dari 130 karangan.

\section{DAFTAR RUJUKAN}

Alwasilah, A Chaedar. 2002. Pokoknya Kualitatif Dasar-Dasar Merancang dan Melakukan Penelitian Kualitatif. Jakarta: Pustaka Jaya

Goto, Rie. 1998. "Ronsetsubun no Bunshoukouzou to Midashibun no Hanpuku”. Nihonjoshi Daigaku Daigakuin Bungaku Kenkyuuka Kiyou. Vol.5. Tokyo: Nihonjoshi Daigaku.

Guba, Egon B dan Yvonna Lincoln. 1985. Effective Evaluation. San Fransisco: Jossey-Bass.

Harasawa, Itsuo. 2012. 'Nihongo ShoChukyuu Gakushuusha no Sakubun Shidou

- Gakushuusha no Goyou Bunseki o Moto ni”. Shizuoka Daigaku Kokusai Kouryuи Sentaa Kiyou. Vol.6. Shizuoka: Shizuoka Daigaku kokusai Kouryuu Sentaa.

Ichikawa, Takashi. 1978. Kokugo Kyouiku no tame no Bunshouron Gaisetsu. Tokyo: Kyouiku Shuppan Kabushiki Gaisha. 
Kanai, Hayato. 2015. "Kankokugo Washa to Chugokugo Washa no Shijishi (So to A) no Goyou - Kyouyuu Chishiki towa Nanika To Iu Kanten kara -". Saitama Daigaku Nihongo Kyouiku Kiyou. Vol.9. Saitama: Saitama Daigaku

Noda, Hisashi. 2005. Komyunikeson no Tame no Nihongo Kyouiku Bunpou. Tokyo: Kuroshio Shuppan

Sakuma, Mayumi. 1990. "keesu 1 Setsuzoku Hyougen (1)". Keesu Sutadi Nihongo no Bunshou Danwa. Tokyo: Oufu.

Sakuma, mayumi. 1995. "Chuushinbun no Dan Toukatsu Kinou”. Nihonjoshi Daigaku Kiyou Bungakubu. Vol.44. Tokyo: Nihonjoshi Daigaku.

Sakuma, Mayumi. 2000a."Bunshou Danwa ni okeru Dan no Kouzou to Kinou”. Waseda Daigaku Nihongo Kyouiku Sentaa Kiyou. Vo.19. Tokyo: Waseda Daigaku Nihongo Kyouiku Sentaa.

Sakuma, Mayumi. 2000b. Nihongo no Bunshou Danwa ni Okeru Dan no Kouzou to Kinou. Heisei 9 nendo 11 nendo Kagaku Kenkyuuhi Hojokin Kiban Kenkyuu (C) (2) Kenkyuu Seika Houkokusho. Tokyo: Waseda Daigaku Nihongo Kenkyuu Sentaa.

Subandi. 2007. Persepsi Masyarakat Jepang Terhadap Ragam Bahasa Wanita Bahasa Jepang. Unesa: Laporan Penelitian Fundamental tidak diterbitkan Sunagawa, Yuriko. 2000. "Danwa Shudai no Kaisousei to Hyougen Keishiki". Bungei Gengo Kenkyuu Gengohen. Vol.38. Tsukuba: Tsukuba Daigaku.

Tanaka, Mai. 2015. "ICLEAJ Sakubun Korpusßni Okeru Nihongobogowasha to Chuugokujin Kankokujin Nihongogakushuusha ni Yoru Omou no Shiyo Joukyou ni Tsuite”. Doshisha Daigaku Nihongo Nihonbunka Kenkyuu. Vol. 13. Kyoto: Doushisa Daigaku

Tashiro, Hitomi. 2005. "Nihongo Gakushuusha no Sutori Setsumeibun no Mondaiten -Wakarinikusa to Iu Kanten kara -". Gengo Bunka to Nihongo Kyouiku. Vol. 30. Tokyo: Ochanomizu Joshi Daigaku 
Parwati Hadi Noorsanti, Diatesis (TAl) dalam Bahasa Jepang...(hlm. 72 -97)

Tashiro, Hitomi. 2006. "Nihongo Gakushuusha no Bunshou no Wakarinikusa ni Kansuru Jissho Kenkyuu -Sutori Setsumeibun to Ikenbun no Baai -. Gengo Bunka to Nihongo Kyouiku. Vol. 32. Tokyo: Ochanomizu Joshi Daigaku Tashiro, Hitomi. 2009. "Yomite no Hyoukabetsu ni Mita Nihongogakushuusha no Ikenbun no Mondaiten -Sutori Setsumeibun to Ikenbun no Baai-". Yokohama Kokuritsu Daigaku Ryugakusei Sentaa Kyoiku Kenkyu Ronshuu. Vol.16. Yokohama: Yokohama Daigaku

Teramura, Hideo. 1990. Keesu Sutadi Nihongo no Bunshou Danwa. Tokyo: Oufu.

Tsuchida, Kazumi dan Imai, Midori. 2007. "Ryugakusei ni Taisuru Koukateki na Akademic Writing no Shidouhou Oyobi Kyouzaikaihatsu no Tame no Kisokenkyuu". Oubirin Daigaku Gengo Kyouiku Rongyou. Tokyo: Oubirin Daigaku

Tokieda, Motoki. 1950. Nihon Bunpou Kougohen. Tokyo: Iwaba Shoten.

Yo, Ha. 2014. "Chuukyuu Nihongogakushuusha no Sakubun ni Okeru Konnanten - Bunkouzou no Kooukankei ni Tsuite -”. Akita Daigaku Kokusai Kouryuu Sentaa Kiyou. Vol.3. Akita: Akita Daigaku. 